\title{
Energy sovereignty and development planning: the case of Maputo,
}

\section{Mozambique}

\author{
Abstract \\ Energy sovereignty refers to people's capacity to take decisions about energy planning. It emphasises \\ the role of energy services in everyday life. This refers both to the quality of energy services and the \\ inequalities in service provision. Energy sovereignty supports policy agendas to deliver energy access in \\ local settings. It is an alternative to energy security. Energy security casts energy planning at the national \\ level. In contrast, energy sovereignty brings energy questions close to people's homes. \\ This paper focuses on Chamanculo C, a neighbourhood in Maputo (Mozambique). The analysis \\ illustrates three dimensions of energy sovereignty. First, energy sovereignty emphasises a reciprocal \\ relationship between society and ecosystems. Second, energy sovereignty advocates self-determination \\ in relation to business models and technologies. Third, energy sovereignty promotes participation in \\ decision-making and innovation. Development planning scholars can deliver an innovative research \\ agenda on energy sovereignty. This should be an action-oriented agenda. It should emphasise \\ opportunities to form partnerships and enhance collaboration. It should put social justice at the centre \\ of energy debates.
}




\section{Introduction}

Achieving affordable and clean energy is one of the Sustainable Development Goals (SDG7). The United Nations have declared the decade 2014-2024 as the decade of Sustainable Energy for All. The challenge is massive. Figures published alongside the Sustainable Development Goals suggest that one in five people still lack access to electricity. Three billion people rely on wood, coal, charcoal or animal waste for cooking and heating. There are also trade-offs between providing energy access and reducing global carbon emissions.

This challenge requires understanding how local conditions shape energy services. People having physical access to an electricity network may lack an appropriate supply of electricity because the supply is intermittent, they cannot afford continuous supply, or the supply does not match their needs (Pachauri and Spreng 2004). Fuel stacking is common. Access to modern fuels does not guarantee essential services if habitation conditions are inadequate. International policy is moving towards energy access policies that reflect the local conditions of energy provision (International Energy Agency and World Bank 2015). Planning is essential for the provision of energy services tailored to local conditions (Practical Action 2016).

Action for sustainable energy emerges within government institutions, business organisations, and grassroots movements (Bulkeley, Castán Broto et al. 2014, Simon 2016). Partnerships between local governments and communities support resilient societies (Bartlett and Satterthwaite 2016). Still, there is little recognition of the role that communities play. Instead, sustainable energy is often framed as a matter for technical experts. Development planning can contribute to sustainable energy debates in three key ways: it can deliver new conceptual frameworks that integrate notions of justice, deliver forms of collaboration and partnership, and challenge the political economy of energy in specific locations. 
The concept of energy sovereignty foregrounds energy questions in development planning. This paper elaborates the concept of energy sovereignty by building on theoretical thinking emerging from the food sovereignty movement. Energy sovereignty has three dimensions. First it emphasises reciprocal relationships between society and ecosystems. Second, it promotes action to establish local control of energy resources and infrastructures. Third it advocates that local people should take part in energyrelated decisions. A case study in a neighbourhood in Maputo, Mozambique, illustrates these three aspects of energy sovereignty.

\section{Energy security and the political economy of energy}

Energy access challenges are commonly approached from top-down perspectives. These perspectives emphasise the role of finance in delivering energy access and encourage governments to adopt a menu of energy options (Brew-Hammond 2010). They advocate managing energy options like an investment portfolio. National concerns take precedence over household's perspectives.

Studies of the political economy of energy criticise expert-led assessments (e.g. Büscher 2009, Pegels 2010, Marktanner and Salman 2011, Khennas 2012). They do not take for granted the social and material context (Büscher 2009). Political economy perspectives challenge old assumptions that persist despite evidence to the contrary. For example, they challenge the assumption that developing nations are willing to trade environmental quality for quick development advancements (already expressed for example in: Hulscher and Hommes 1992). Political economy perspectives link energy provision and local conflicts (Haselip and Romera 2011, Luque-Ayala and Silver 2016), provide evidence of the impact of global energy trade on the environment and on the lives of people (Meierding 2011), and study asymmetries in finance and technology for low carbon development (Gujba, Thorne et al. 2012).

Yet, political economy perspectives are not a panacea. They can slip into a homogenizing discourse with ready-made solutions for complex problems. Analyses of the geopolitics of energy often fall into this 
trap as they lack engagement with people's experiences of energy access. They often overlook ethnographic, place-specific research on energy (Büscher 2009) and generate batteries of solutions, like studies from a technical perspective. They may propose more infrastructure, more economies of scale, more resource imports, and more decentralization (e.g. Khennas 2012). Political economy analyses explain the governance context of energy access, but struggle to explain the challenges to energy access that emerge in everyday life.

For example, we are still short of policy-relevant research at the household level. Researchers' attention is often turned elsewhere to study the 'root causes of the energy access dilemma' (Sokona, Mulugetta et al. 2012; pp 6-7). Studies that link energy access to income-generation pay little attention to actual energy uses (Brew-Hammond and Kemausuor 2009). When technology is available, research focuses on barriers to adoption. Attempts at participation are insufficient (e.g. Glemarec 2012) and analyses of the actual impact of energy access policies on people's livelihoods are rare.

Detailed, place-specific work can throw insights into how to deliver energy access. For example, a study of energy provision in rural areas of northern Ghana showed that energy needs are similar across different villages. This is also true for villages that have access to the electricity network or to decentralised solar technologies (Kankam and Boon 2009). A survey in the city of Maun, Botswana, observed an almost universal use of commercial-'modern' - fuels. Yet, households used other fuels to manage unstable fuel prices (Hiemstra-van der Horst and Hovorka 2008). The embeddedness of fuels and appliances in daily practices is not well understood. Still, an understanding of the local conditions for energy access is crucial to deliver energy to meet everyday energy needs.

\section{Defining energy sovereignty}

The word 'sovereignty' refers to the authority of states to govern. In relation to land and resources, sovereignty raises questions about who can control them. In this sense, ideas of energy sovereignty 
have the potential to challenge accepted paradigms about who decides energy access policies. The concept points towards who has autonomy to define energy resources availability.

Insights from three decades of debates on food sovereignty can inform energy sovereignty thinking. Resource sovereignty initiatives are transformative (Rosset 2009, Edelman, Weis et al. 2014). Ideas of food sovereignty have galvanised action in transnational agrarian movements such as the emblematic movement La Vía Campesina (LVC). Food sovereignty has inspired national legislation changes in countries such as Ecuador or Senegal.

Food sovereignty is most often defined as an alternative to food security (Patel 2009, Edelman, Weis et al. 2014, McMichael 2014, Trauger 2014). Food security emphasises the availability of food. Food sovereignty, instead, directs attention to the rights of people and communities to determine their relations to food and food production.

Energy sovereignty also calls for a distinction between energy security and energy sovereignty. Energy security emphasises the availability of energy resources at the national level. For example, Ekins (2016; $\mathrm{np}$ ) says that energy sovereignty is "the ability of a nation state to promote its best interests". This notion does not address concerns about energy access that emerge in relation to the provision of daily services. Principles of national security are also anachronistic in the context of development (McMichael 2014). Control over energy resources at the national level is often a means to perpetuate elites' power (Meierding 2011). There is not a perfect match between states' interests and communities' interests. Moreover, states have little discretionary power over utilities and multi-national energy companies. Instead, energy sovereignty locates 'sovereignty' in people's opportunities to promote their best interests.

Energy sovereignty highlights social inequalities embedded in contemporary energy systems. Such inequalities may relate to conflicts around the extractive industries (e.g. Haselip and Romera 2011) and 
may also emerge within everyday life practices and the discourses that frame them. The confluence between neoliberal state policies and global capital circulation causes energy insecurity. Thus, energy sovereignty mirrors food sovereignty challenges (e.g. Trauger 2014). Energy policy processes often overlook the interests of energy users in favour of grand narratives of energy access and energy security expressed at the national or global levels. Such narratives privilege the operation of large, multinational, and non-transparent companies for resource exploitation and energy provision. Ideas of 'comparative advantage' and 'economies of scale' favour resource monopolisation and centralised systems. The first step towards developing a place-based understanding of energy access is understanding the local conditions of energy provision. In the same way, contextual knowledge is at the centre of the food sovereignty movement (Martínez-Torres and Rosset 2014, van der Ploeg 2014).

Energy sovereignty has three components (cf. McMichael 2014). First, energy sovereignty connects energy provision with ecologically responsible relationships with energy resources; such relationships should recognise the territorial conditions of energy provision. Second, energy sovereignty challenges grand narratives energy that do not prioritise delivering energy to households. Third, energy sovereignty calls for democratising energy systems. This is akin to giving a meaningful voice to users and those affected by energy developments. It also means mobilising contextual knowledge for the management and development of energy technologies. What does the energy sovereignty paradigm mean in practice? To discuss this, the next section presents an urban case-study in Maputo, Mozambique.

\section{Urbanisation and energy access in Mozambique}

Mozambique is one of the poorest countries in the world and is at the bottom of UNDP's rank of nations according to the Human Development Index. Life expectancy in Mozambique remains below 50 years old. Even so, the country has made remarkable progress over the last 20 years (United States Agency for 
International Development 2011). The provision of services in urban areas has improved, but it remains deficient.

In the post-independence period, the ruling party, Frelimo, overlooked the development of urban areas (Grest 1995). Frelimo saw urban areas as repositories of colonial power. Urban population grew during the 1980s and early 1990s, with an estimated 9 million urban dwellers (32\% of the population) by 2015. Mozambican urban centres struggle to meet the needs of a growing urban population. In the last two decades, infrastructure interventions have benefited suburban areas where the majority of the urban population lives (Center for Habitat Studies and Development 2006). Still, struggles for housing and services characterise urban life (Jenkins and Wilkinson 2002).

The poor state of infrastructure in Mozambican cities also reflects how it is governed. Institutional thinness and weak political involvement of citizens hinder service delivery (Jenkins 2000, Jenkins and Wilkinson 2002). For Jenkins (2013), urban dwellers lead the process of urbanisation, hence Maputo is urbanising from below. Growth takes place in peri-urban areas through residents' homemaking practices, making home spaces the unit of urban organisation. Residents have limited expectations of municipal action in the provision of urban infrastructure.

Local associations or 'Grupos Dinamizadores' operate in local neighbourhoods developing services including roads, sanitation, waste collection, and electricity. These 'Grupos Dinamizadores' enrol citizens in service provision. Citizens also have to make concessions for demolitions to build new infrastructures (Center for Habitat Studies and Development 2006). Citizen-based services constitute a key part of urban life. In many Maputo neighbourhoods, citizen groups 'stand for the state' providing otherwise inexistent services (Nielsen 2010).

The empirical analysis section has two parts. The first is an introduction to the political economy of energy. This review links local energy struggles to broader processes of material transformation. The 
second part is an analysis of what energy sovereignty means in context and why it matters to urban dwellers. The analysis looks into the significance of energy in daily life in a neighbourhood of Maputo, Chamanculo C. The analysis focuses on 23 semi-structured interviews, with 28 participants ( 9 female and 17 male). The interviews took place between July and December of 2014. A coding guide which explores the three dimensions of energy sovereignty supported the analysis. First, it focuses on the relationship between energy provision and ecological transformation. Second, it examines the autonomy and control of local residents in relation to the dominance of big corporations or other actors over resources and technologies. Third, it assesses the capacity of urban dwellers to intervene in decision-making processes. The analysis also refers to the author's previous work including a report from a participatory workshop to map energy needs in Chamanculo C (Castán Broto, Salazar et al. 2014), and an energy access survey of 40 households (Castán Broto, Stevens et al. 2015).

\section{The political economy of energy in Mozambique}

There are large deposits of natural gas in the Rovuma Basin, in northern Mozambique. This recent discovery has attracted international attention and is likely to change fundamentally the political economy of energy in Mozambique. Potential investors have rushed to the region of Cabo Delgado in northern Mozambique (Court and McCarthy 2015). Initially, there were international concerns about the viability of these investments (e.g. England 2015). However, in 2016 corporations such as Anadarko, Galp and Eni Group announced investments in the deposit. Activists in Mozambique argue that these investments do not benefit the country (Hanlon and Nuvunga 2015).

The discovery of gas deposits mirrors the discovery of coal resources a decade earlier. News of the 'Moatize coal deposit', in Tete, another poor northern province, raised financial interests. The Brazilian company Vale led the consortium that won the rights to exploit Moatize in 2004. A rush of smaller investments followed (Hatton and Fardell 2012). Multinational companies organised themselves in 
enclaves in Tete. As Kirshner and Powell (2015) explain, local people see few benefits from these enclaves. Instead, fuel resources are exported. This export orientation has visible consequences. For example, new deposits have redefined the economic centres and peripheries within Mozambique, inserting local extractive industries in international flows. Overall, they have excluded local populations from any possible benefits (Kirshner and Power 2015).

Prioritisation of resource extraction and export markets characterises the energy sector in Mozambique (Mulder and Tembe 2008). Hydropower still provides the majority of electricity in the country. This amounts to $9 \%$ of the total energy balance (Cuvilas, Jirjis et al. 2010). The dam in Cahora Bassa, in the province of Tete, still provides most electricity (Ahlborg and Hammar 2014). Mozambique consumes only $15 \%$ of the electricity, exporting $85 \%$ of the electricity produced in the dam to South Africa, Zimbabwe, and Namibia (Sebitosi and da Graça 2009). In South Africa, exports support a wheeling agreement between the South African utility ESKOM and Electricidade de Moçambique (EDM). This agreement also provides electricity to the capital Maputo in the more prosperous southern part of the country. There is little evidence that the construction of the Cahora Bassa Dam in the 1960s and 1970s supported the development of the north western region of Mozambique.

The ruling party Frelimo has promoted the use of biofuels since 2004. They argue that unused land can produce biofuels. Their dream was to transform Mozambique into an 'oil exporting country' (see, for example: Schut, Slingerland et al. 2010). In southern Africa countries, biofuels are often associated with land grabbing (Borras Jr and Franco 2012). Mozambique is not an exception. Lands which are considered unused may play a key role sustaining local livelihoods (Borras, Fig et al. 2011). The species jatropha performs poorly in the agro-climatic conditions of Mozambique. Still, the government has made large land deals based upon the use of this plant. Deals with international biofuel investors have not brought benefits to local populations (Hall 2011).Civil unrest and protests have followed such deals. Like natural gas, coal, and hydropower, biofuels emerge as an energy resource for exports. None of them seem to 
have significant local benefits. These extractive economies connect to energy sovereignty issues. They explain that investors' interests influence decisions about resources and land transformation. Investment priorities support international flows of capital over local exchanges.

Electricity distribution markets are a means for territorial control in both urban and rural areas (Power, Newell et al. 2016). Electricidade de Mocambique (EDM) dominates the distribution network. Achieving universal energy access is an explicit goal for EDM. Still, EDM prioritises the development of energy resources. In 2016 EDM started an investment plan of USD18 billion over 15 years, funded by the African Development Bank. The plan proposes alternatives for energy provision. Renewable innovations provide alternatives for electricity generation with a direct local impact. This provides access for households not connected to the electricity grid (Cuamba, Chenene et al. 2006, Ahlborg and Hammar 2014). Yet, renewable alternatives do not challenge the model of energy investment. Moreover, they do not engage with the energy needs of the urban poor.

Charcoal and firewood support Mozambican households (Brouwer and Magane 1999, Brouwer and Falcão 2004) accounting for up to $81 \%$ of the total energy consumed in Mozambique (Cuvilas, Jirjis et al. 2010). Charcoal is the most common fuel in urban areas. Charcoal, firewood, and even waste continue to be a key source of energy for households, and coexist with much rarer electricity and gas networks.

\section{Everyday energy challenges in Maputo}

The wheeling agreement with ESKOM benefits Maputo directly (Vasco and Costa 2009). The city has the highest electrification rates of the whole country. Still, energy access problems are rampant. Material, economic, and social factors constrain households' access to energy. The division of Maputo in two cities is strong in the local imagination. One is the 'cement city' which includes the central area with infrastructure dating back to the colonial era. The other city is 'the reed city' (cidade de caniço) which includes the surrounding neighbourhoods, called bairros, with larger deficiencies in service provision. In 
colonial times, bairros constituted a reservoir of labour for the colonial city where huts were built with reeds. Today the worlds of the reed and the cement city intersect. The integration of formal and informal processes in everyday life challenges this urban divide. However, this separation persists in the imagination of Maputo's residents and visitors, and in design practices and resource uses. For example, expectations of electricity provision differ across this divide. The supply and use of energy is spatially differentiated. In 'the cement city' both electricity and LPG are available. In contrast, the bairros are characterized by the ubiquitous presence of charcoal in markets and public areas.

Figure 1 provides an overview of energy provision in Maputo's households. It provides an approximate representation of different systems of provision. There is a spectrum from the families that use electricity and Liquefied Petroleum Gas (LPG) to the poorest families that can only access poor quality fuels. The majority of households combine the use of charcoal with a limited use of electricity. The continuity of the electricity service depends on the location of the household and how much electricity they can actually afford. The arrows in Figure 1 show the direction of growth. There is a trend towards improving the quality of the electricity supply and extending the coverage of LPG over the city.

\section{[INSERT FIGURE 1 HERE]}

Baptista $(2015 ; 2016)$ argues that the prepaid system is 'the default electricity retail model in Maputo'. She claims that Maputo's residents have embraced the prepaid system as it enables them to have control of electricity consumption (Baptista 2015b; p. 1004). This control has enabled households to maintain access to the electricity grid. Prepayment links to the question of 'autonomy'. The system enables urban dwellers to understand what they consume. Residents can buy smaller units and adjust their consumption to resources available. 
Charcoal is also embedded in an economic system that enables control and autonomy over energy resources. Charcoal flows depend on different occupations across the city. Fractioning charcoal means that supply happens through different business models (Mavhunga 2013).

The possibility to fraction amounts has facilitated the integration of both the pre-paid system and charcoal flows in the everyday practices of energy use in Maputo (Castán Broto, Salazar et al. 2014). The situation in Maputo highlights the intricacy of energy sovereignty questions in an urban context. Such questions relate to everyday energy challenges. In the following section we examine the observations of institutional representatives, local business managers, and local community representatives. These observations link contemporary understandings of energy services to the three dimensions of energy sovereignty.

\section{Energy sovereignty in an urban context}

The case study reveals the multidimensional nature of energy sovereignty in Chamanculo C. Table 1 summarises the elements of analysis and each section.

[Insert Table 1 near here]

\section{Connection to socio-ecologically responsible relationships}

The first aspect of energy sovereignty connects energy provision to ecologically responsible relationships. This means looking into the use of energy resources and their territorial context. Concerns about the destruction of marine habitats have already emerged in the Rovuma Basin. The role that extractive industries play in transforming the landscape is tangible. Energy production requires dramatic landscape transformations.

The role of distribution companies is equally dramatic, but frequently ignored. Distribution companies link their expansion to issues of territorial control. For example, a representative of EDM explained that 
“...EDM is 'all terrain'. We arrive [to remote locations] before any other company". Petromoc is Mozambique's state-owned distributor of petroleum. A Petromoc representative boasted about their 'full coverage' of the territory. New multinational companies arrived in Mozambique after the liberalization of fuel markets. Yet, none of these companies have reached the territory of Petromoc, this representative argued. The territorial coverage is a point of pride for both EDM and Petromoc.

Distribution companies control the location and expansion patterns of electricity networks. They manage a process of spatial differentiation in energy services. Some areas appear as being more deserving than others. Spatial differentiation is a key tool for energy governance. An EDM employee explained that:

There is a difference, because there are lines... that are for the VIPs. This is the case of the line that supplies the Central Hospital, the one that supplies the Quartel General, and the one that supplies the presidential area.

In Chamanculo C, residents do not question any infrastructures or their distribution. Instead they raise ecological concerns about the changing relationship with charcoal and firewood. A community representative explains: "...there are a few communities that use firewood, but the reason is very simple. Bushes are too distant from the city and transporting firewood is more difficult than transporting charcoal". Transport costs reduce the price difference that generally makes firewood cheaper. Nevertheless, transects through Maputo's neighbourhoods show that firewood is still in use. In neighbourhood near green areas, firewood collection is a regular activity alongside urban agriculture.

Local communities also value urban forest resources. Their livelihood practices are embedded in a set of ecological relations which include these resources. For example, during a workshop participants debated the contribution that neighbourhood trees made to heat management in households: 
Here in our neighbourhood we protect trees ... because they contribute to cooling... the houses. Because many of them are made of wood ... and metal sheets. When it is very hot, [it is also] too warm inside... If you have a tree, at least it gives some shadow and the house does not heat up that much.

This relationship between the city and the local flora is visible in the landscape of the neighbourhood. Houses (often a string of separated rooms) congregate around courtyards. In these courtyards, trees and plants grow alongside chicken and children. Remittances and new economic opportunities have increased the flows of capital in the neighbourhood. Some bairro residents rebuild and extend their houses. They may cut trees, encroach on collective spaces, and reduce the land available for the construction of new infrastructure. Any infrastructure development requires negotiating such public spaces and collective resources.

There is less attention to the dependence of the neighbourhood on distant resources. During fieldwork, an interview took place with a charcoal producer who lived in the hinterland of Maputo. Walking in the forest he explained how he selected tree species. In front of his kiln, he explained the technology involved in burning the wood and described charcoal production as a subsistence activity:

...charcoal here can save a life. When somebody does not have any money, does not have anything, they can come here and cut one, two, three [trees] and already you have a bag of charcoal, you have something to eat at home.

Charcoal offers a safety net in the most extreme situations. It also provides a flexible alternative that producers can engage with when no other livelihood means are available. In Mozambique, charcoal production is linked to deforestation (Sitoe, Remane et al. 2016) which is intensive in the hinterland of Maputo (Ellegård and Nordström 2003). Charcoal production supports livelihoods at a considerable environmental cost (Zulu and Richardson 2013). 
Specific social and material relationships shape energy access. However, while the maintenance of socio-ecological relations within the neighbourhood requires ongoing negotiation, big companies are able to transform the energy landscape with little or no accountability.

\section{Self-determination in relation to business models and technologies}

Energy sovereignty challenges technological and economic models of energy use. This means challenging hegemonic policies as well as asserting the value of local technologies and local management systems. There is ambiguity between finding reliable means to provide energy services and scrutinising them against potential alternatives.

The pre-paid system is an example of this ambiguity. Residents in bairros generally see the prepaid system as a great advancement. Our household-based research corroborates findings by Baptista (2015b, 2015a, 2016). Institutions are also satisfied with the prepaid system. EDM plans to ease prepayment by using ATMs and mobile phones.

Energy sovereignty fosters an in-depth discussion of the structural conditions that favour specific policies or business models. What makes the prepaid system successful? Social inequalities prevent households from keeping up with subscription payments. Electricity providers struggle with inadequate regulation and chronic deficiencies in infrastructure. There are no decentralised alternatives. Is the prepaid system a neoliberal instrument? Does it matter when the conditions of energy provision make it the best alternative?

People's experiences of energy also relate to the extension and improvement of the electricity system. EDM argues for an incremental expansion of infrastructure. A key aspect here is prioritisation. How do EDM (and financing institutions) prioritise infrastructure extensions and improvements? For example, the building and repairing of transformation posts (PT) is essential to maintain electrification in different neighbourhoods. An institutional representative explains: 
In Maputo ... there are places that need the installation of a new PT but the cost and limited number of consumers do not justify this intervention.

Determining the number of consumers is a complicated process. Such calculation privileges formal habitation and favours communities whose members can navigate the institutional setting. This understanding of 'the consumer' does not consider actual conditions of living. Figure 1 demonstrates that there are many ways of being an energy consumer in Maputo. Moreover, those who may need electricity the most do not yet have access to it.

Moreover, there are alternative guiding principles for network improvements which do not follow a crude headcount of users. EDM acknowledges the designation of VIP areas. In the city, improvements to the electricity network and public lighting are visible in gentrifying areas. New infrastructure is being built alongside the new avenue Julius Nyerere, which hosts large mansions, luxury hotels, and public schools. In neighbourhoods like Chamaculo C, where relocation is out of the question, communities struggle to maintain the PTs. PTs in flood-prone areas are most at risk.

Development planning is concerned with the relationship between territorial models of organization and the delivery of services. Energy policy in Mozambique assumes the separation between urban areas and rural areas. This translates into two models of energy provision. One model focuses on developing a centralised network to provide electricity (and LPG). This is the standard EDM model. The other model, for rural areas, focuses on using renewables and decentralised systems. EDM may implement some of these projects, however, communities also deliver decentralised projects. None of these models address the consumption of firewood or charcoal.

Reality transcends both models, because both centralized and decentralized modes of provision coexist in rural and urban areas. Sometimes both are absent. The very definition of what is urban or rural is not clear. Moreover, these models do not constitute a template for future aspirations. How do they 
acknowledge the need for a reliable energy supply in rural areas and the need for control and autonomy in urban areas? They exclude rural areas from the centralised network and they also exclude urban areas from the opportunities of decentralised systems. This distinction only reinforces the regional inequalities in the national energy system.

In urban settings, the dominance of charcoal and the popularity of the pre-paid system reflect a preference for business models that enable self-determination. Charcoal is produced in small quantities. It circulates from the urban hinterland to the city in progressively smaller amounts. The charcoal network constitutes an alternative to obscure systems of distribution for electricity and petrol. When it comes to charcoal, local business people control the whole chain. Similarly, the pre-paid system has given families autonomy in relation to the control of their own electricity consumption.

Communities should also have control over technologies. Since 2014, a cookstove improvement programme has revolutionised cooking and charcoal use practices in two bairros (Chamanculo and Xipamine). Do improved cookstoves match the actual cooking needs of the community? To a certain extent, yes. Residents praise new cookstoves because charcoal lasts longer and there is less pollution. Users of new appliances cook inside their houses whereas with the old cookstove they had to cook in the courtyard.

Improved cookstoves are too small, and hence, residents use them alongside traditional cookstoves. For example, traditional ones are big enough to heat water throughout the day. Improved cookstoves have 'one mouth'. Most households cook in 'two-mouth' cookstoves that facilitate the simultaneous preparation of different components of a meal. These issues raise questions about the extent to which improved cookstoves match local design needs. Energy sovereignty links to architecture and design.

Improved cookstoves and traditional ones represent the encounter of global and local flows of technology. As improved cookstoves are imported from the United States, they insert the community in 
global flows of technology. They displace old iron cookstoves which are locally built and widely available in local markets. There are incentives to switch from traditional to improved cookstoves that make them economically competitive. However, there is a limited understanding of the impact of abandoning traditional cookstoves. Does this mean a loss of skills? Will the neighbourhood become dependent from an international producer? Will the improved cookstoves change the design and use of home spaces?

\section{Participation in decision-making and innovation}

Energy sovereignty emphasises participation in decision-making and innovation. Diverse groups within society should have a meaningful voice in the management and delivery of energy services. In Maputo, communities can shape strategic projects of infrastructure development and improve the knowledge base. They can also challenge erroneous assumptions about the provision of energy in their neighbourhoods.

Community representatives emphasise that 'having communication' is the first step to work with energy providers who allocate responsibilities for communication to different institutions. They put themselves at one end of the chain:

The Ministry of Energy has contact with the district and we bring the community affairs to the district... [that is] to the Conselho Municipal. The Conselho Municipal then channels [the community affairs] to other levels. We have a direct relationship with the company, EDM. Whenever something happens we can contact them, for example, by telephone, so that we can report what is happening and they can respond. These are mostly cases of breakdowns and faulty equipment.

Community dwellers can support the maintenance of infrastructure equipment by reporting failures and keeping a close watch on its operation. There is less recognition, however, of the role that communities 
can play in strategic projects of energy provision. There have been institutional attempts to involve them:

Yes, [institutions] attempt to do community engagement, they attempt to engage... In some bairros they establish ... 'an energy committee', whereby the communities can act in partnership with EDM. But I feel that this engagement is not very effective. They design certain policies and then there is not a real management of those policies in the bairro... In our neighbourhood, I know there is such committee. But if you ask anyone when was the last time that EDM met the committee, they will tell you that it was three or four years ago. There is no interaction, no dialogue, no following up of policies for communities...

Community members think that there are already public policies that address their needs. Yet, they perceive a gap between this rhetoric and its actual implementation. Such a gap is apparent even though citizens have seen vast material improvements in the provision of energy during the last ten years.

They also explain that services providers have organised engagement activities. However, these mostly focus on disseminating information. There is less interest in listening to the community, let alone enrolling citizens as active agents of change. Rather, public engagement is seen as an activity promoting community education. The objective is to mould people's behaviours. In Chamanculo C, for example, a participatory process took place during the implementation of the prepaid system:

I am not going to say that there was any consultation, there was no consultation. Instead, there was some divulgation: they told us that they were going to change the system and the community welcomed it, true, [although] some were sceptical...

The education rhetoric is so powerful that community members have internalised it. Community members argue for the need to educate themselves. They want to change 'people's mentalities'. For example, a community member explained the success of the prepaid system as follows: 
...the pre-paid system also changed the behaviour of the community in relation to the use of energy, we did not need any additional programme for education. The system itself educated the community that could then understand how to operate the system in relation to its use.

The underlying assumption is that the pre-paid system promotes 'the right behaviours'. This matches the educational aspirations of institutional representatives. Communities may see the pre-paid system as a means for autonomy and control but institutional representatives see it as a means for educating consumers into market principles. A representative from the Ministry of Energy explained the need for such education. A 'change of mentality', he said, is essential to convince people that they have to pay for such services:

So if I tell you 'to have energy in your household, to have water, you need to pay. Three thousand meticais [1 Metical=0.014 USD\$], four thousand, five thousand, ten thousand... all that money because you want to have electricity... This is an automatic realization. It is a critical factor.

In his view, citizens have to understand that they have to pay for services. Educational aspirations aim at shaping behaviours to fit global models of service provision rather than meeting local needs. Another example relates to the misrepresentation of energy faults from energy thefts. The evidence from planning documents and community consultations is that electricity theft is rare in Chamanculo C. Yet, electricity theft is at the core of conflicts with EDM:

Sometimes, the supply is reduced in some areas at the end of the day ... Later the utility accuses the community saying that there is electricity theft, because the electricity supplied to that community is sufficient to maintain a constant supply.

There are several factors that affect the supply: lack of investment in infrastructure, shortages of fuel, and supply uncertainties. Still, an emphasis on theft allocates all responsibility to local residents. This 
occurs regardless of what residents do. The pre-paid system has helped solve these disagreements and some argue that it enables controlling theft within the community. Our fieldwork shows, however, that the prepaid system has made explicit the transactional relationships between EDM and the community:

Yes, people are happy [with the pre-paid system], because at some point they felt that they were being robbed by [EDM]. There were communities that consumed little but had to pay a lot. There were those that consumed a lot, and did not pay anything. Those practices brought a conflict between the consumer and the company. When we changed [to the pre-paid system] the issue was solved.

In other words, the pre-paid system demonstrates lack of theft. This recognises community needs and challenges established assumptions about how they use electricity.

\section{TOWARDS ENERGY SOVEREIGNITY}

The notion of energy sovereignty raises old questions. What is the social function of energy and of access to energy resources? How does energy access relate to the distribution of rights and responsibilities? Do communities participate in decision-making processes? These are questions of energy justice that are gaining currency in energy debates (Goldthau and Sovacool 2012). Energy sovereignty challenges energy access perspectives that emphasise national strategy at the expense of local understandings of energy. It emphasises the relevance of local understandings of energy in multiscalar forms of energy planning and recognises the distribution of agency at different levels.

The case of the neighbourhood Chamanculo C, in Maputo, demonstrates the cultural embeddedness of energy in everyday life. Energy access is not only shaped by the political economy of energy but also by its manifestations in specific locations. Energy sovereignty invokes a global movement which attends to local sensibilities and consequences. It highlights the provision of energy in everyday life, how it supports people's livelihoods, and the extent to which they can have a say in the provision of 
infrastructure which will shape their future. These aspects become explicit in the context of development planning in urban settings, such as in the case of Maputo, and link to broader questions about the political economy of energy in Mozambique.

Developing an energy sovereignty agenda will require analyses that engage with the social function of energy. There is already a growing interest within the social sciences in energy questions (Sovacool 2014). Yet, there are some specific aspects that only development planning can tackle. First, development planning analyses socio-ecological arrangements and how they manifest in material flows that shape the interface between rural and urban areas. Second, development planning relates the delivery of specific business and technological models to the actual means whereby people who lack reliable energy access may construct a sustainable livelihood. Third, development planning engages with active processes that can involve diverse publics in processes of decision making for energy planning. Development planning has an opportunity to make a step change in this field. As a discipline, it highlights the relationship between spatial development and social justice. Among its prescriptions, it puts ideas of collaboration and partnership at the centre of debates about energy access. This is crucial to deliver decentralised systems of energy provision, over which energy users may have greater control.

\section{REFERENCES}

AHLBORG, H. AND L. HAMMAR (2014). 'Drivers and barriers to rural electrification in Tanzania and Mozambique - Grid-extension, off-grid, and renewable energy technologies.' Renewable Energy 61: 117-124.

BANK, I. E. A. A. W. (2015). 'Sustainable Energy for All 2015 - Progress towards sustainable energy. Washignton DC, World Bank.

BAPTISTA, I. (2015a). 'Maputo: Fluid Flows of Power and Electricity -- Prepayment as a Mediator of StateSociety Relationship'. Energy, Power and Protest in the Urban Grid: Geographies of the Electric City. A. Luque and J. Silver. Abingdon, OXON, Routledge.

BAPTISTA, I. (2015b). 'We Live on Estimates': Everyday Practices of Prepaid Electricity and the Urban Condition in Maputo, Mozambique.' International Journal of Urban and Regional Research 39(5): 10041019.

BAPTISTA, I. (2016). 'Prepaid electricity in Maputo, Mozambique: challenges for African urban planning'. Urban Planning in Lusophone African Countries. C. N. Silva. Farnham, Ashgate. 
BARTLETT, S. AND D. SATterthWAIte (2016). Cities on a Finite Planet: Towards Transformative Responses to Climate Change, Routledge.

BorRAS JR, S. M. AND J. C. FRANCO (2012). 'Global Land Grabbing and Trajectories of Agrarian Change: A Preliminary Analysis.' Journal of Agrarian Change 12(1): 34-59.

BORRAS, S. M., D. FIG AND S. M. SUÁREZ (2011). 'The politics of agrofuels and mega-land and water deals: insights from the ProCana case, Mozambique.' Review of African Political Economy 38(128): 215-234. BReW-HAmmond, A. (2010). 'Energy access in Africa: Challenges ahead.' Energy Policy 38(5): 2291-2301. BREW-HAMmond, A. AND F. KeMAUSUOR (2009). 'Energy for all in Africa - to be or not to be?!' Current Opinion in Environmental Sustainability 1(1): 83-88.

BROUWER, R. AND M. P. FALCÃo (2004). 'Wood fuel consumption in Maputo, Mozambique.' Biomass and Bioenergy 27(3): 233-245.

BROUWER, R. AND D. M. MAGANE (1999). 'The charcoal commodity chain in Maputo: access and sustainability.' Southern African Forestry Journal(185): 27-34.

BULKELEY, H. A., V. CASTÁN BROTO AND G. A. EdWARDS (2014). An urban politics of climate change: experimentation and the governing of socio-technical transitions, Routledge.

BüSCHER, B. (2009). 'Connecting political economies of energy in South Africa.' Energy Policy 37(10): 3951-3958.

CASTÁn Broto, V., D. SAlAZAR AND K. AdAMs (2014). 'Communities and urban energy landscapes in Maputo, Mozambique.' People, Place and Policy 8(3): 192-207.

CASTÁn BRoto, V., L. SteVEnS AND D. SALAZAR (2015). 'Energy Access and Urban Poverty- Energy and Everyday Life in an Informal Settlement in Maputo, Mozambique'. Poor People's Energy Briefing. Rugby, Practical Action Publishing.

COURT, A. AND D. MCCARTHY (2015). 'Massive gas discovery transforms Mozambique backwater into boomtown, CNN.

Cuamba, B. C., M. L. Chenene, G. Mahumane, D. Z. Quissico, J. Lovseth And P. O'Keefe (2006). 'A solar energy resources assessment in Mozambique.' Journal of Energy in Southern Africa 17(4): 76-85.

CUVILAS, C. A., R. JIRJIS AND C. LUCAS (2010). 'Energy situation in Mozambique: A review.' Renewable and Sustainable Energy Reviews 14(7): 2139-2146.

Development, C. F. H. S. A. (2006). 'Mozambique, Cities without Slums, Analysis of the Situations \& Proposal of Intervention Strategie. Maputo, Eduardo Mondlane University: 1-63.

Development, U. S. A. F. I. (2011). 'Mozambique: Property Rights and Resource Governance Profile. Washington, DC, USAID: 1-27.

Edelman, M., T. Weis, A. BAVISKar, S. M. BorRas, E. Holt-Giménez, D. KandiYoti AND W. Wolford (2014). 'Introduction: critical perspectives on food sovereignty.' The Journal of Peasant Studies 41(6): 911-931. EKINS, P. (2016). 'Brexit backfire? UK actually has more 'energy sovereignty' inside the EU than out.' The Conversation June 9.

ELLEGÅRD, A. AND M. NORDSTRÖM (2003). 'Deforestation for the poor?' Renewable Energy for Development 16(2): 4-6.

ENGLAND, A. (2015). 'Mozambique strives to get liquefied natural gas projects online'. Financial Times. GLEMAREC, Y. (2012). 'Financing off-grid sustainable energy access for the poor.' Energy Policy 47, Supplement 1(0): 87-93.

GoldTHAU, A. AND B. K. SOVACOOL (2012). 'The uniqueness of the energy security, justice, and governance problem.' Energy Policy 41: 232-240.

GREST, J. (1995). 'Urban Management, Local Government Reform and the Democratisation Process in Mozambique: Maputo City 1975-1990.' Journal of Southern African Studies 21(1): 147-164.

GuJBA, H., S. THORNE, Y. MULUGETTA, K. RAI AND Y. SOKONA (2012). 'Financing low carbon energy access in Africa.' Energy Policy 47, Supplement 1(0): 71-78. 
HALL, R. (2011). 'Land grabbing in Southern Africa: the many faces of the investor rush.' Review of African Political Economy 38(128): 193-214.

HANLON, J. AND A. NUVUNGa (2015). 'Gas for development or just for money?' Serviçio de Partillha de Informaçao 8.

HASELIP, J. AND B. M. RoMera (2011). 'Peru's Amazonian oil and gas industry: risks, interests and the politics of grievance surrounding the development of block 76, Madre de Dios.' International Development Planning Review 33(1): 1-26.

HATTON, W. AND A. FARDELL (2012). 'New discoveries of coal in Mozambique - Development of the coal resource estimation methodology for International Resource Reporting Standards.' International Journal of Coal Geology 89: 2-12.

HIEMSTRA-VAN DER HORST, G. AND A. J. HovorKa (2008). 'Reassessing the "energy ladder": Household energy use in Maun, Botswana.' Energy Policy 36(9): 3333-3344.

HULSCHER, W. S. AND E. W. HOMMES (1992). 'Energy for sustainable rural development.' Energy Policy 20(6): 527-532.

JenkINS, P. (2000). 'City Profile: Maputo.' Cities 17(3): 207-218.

JENKINS, P. (2013). Urbanization, Urbanism, and Urbanity in an African City: Home Spaces and House Cultures. New York, Palgrave Macmillan.

JENKINS, P. AND P. WILKINSON (2002). 'Assessing the Growing Impact of the Global Economy on Urban Development in Southern African Cities: Case Studies in Maputo and Cape Town.' Cities 19(1): 33-47. KANKAM, S. AND E. K. BOON (2009). 'Energy delivery and utilization for rural development: Lessons from Northern Ghana.' Energy for Sustainable Development 13(3): 212-218.

KHENNAS, S. (2012). 'Understanding the political economy and key drivers of energy access in addressing national energy access priorities and policies: African Perspective.' Energy Policy 47, Supplement 1(0):

21-26.

KIRSHNER, J. AND M. POWER (2015). 'Mining and extractive urbanism: Postdevelopment in a Mozambican boomtown.' Geoforum 61: 67-78.

Luque-AyAlA, A. AND J. Silver (2016). Energy, Power and Protest on the Urban Grid: Geographies of the Electric City, Routledge.

MARKTANNER, M. AND L. SALMAN (2011). 'Economic and geopolitical dimensions of renewable vs. nuclear energy in North Africa.' Energy Policy 39(8): 4479-4489.

MARTíneZ-TORRES, M. E. AND P. M. RosSet (2014). 'Diálogo de saberes in La Vía Campesina: food sovereignty and agroecology.' The Journal of Peasant Studies 41(6): 979-997.

Mavhunga, C. C. (2013). 'Cidades Esfumaçadas: Energy and the Rural-Urban Connection in Mozambique.' Public Culture 25(2 70): 261-271.

MCMICHAEL, P. (2014). 'Historicizing food sovereignty.' The Journal of Peasant Studies 41(6): 933-957.

MeIERDING, E. (2011). 'Energy Security and Sub-Saharan Africa.' International Development Policy Online: 1-18.

MULDER, P. AND J. TEMBE (2008). 'Rural electrification in an imperfect world: A case study from Mozambique.' Energy Policy 36(8): 2785-2794.

NiELSEN, M. (2010). 'Mimesis of the State: From Natural Disaster to Urban Citizenship on the Outskirts of Maputo, Mozambique.' Social Analysis 54(3): 153-173.

PACHAURI, S. AND D. SPREng (2004). 'Energy Use and Energy Access in Relation to Poverty.' Economic and Political Weekly 39(3): 271-278.

PATEL, R. (2009). 'Food sovereignty.' The Journal of Peasant Studies 36(3): 663-706.

PEGELS, A. (2010). 'Renewable energy in South Africa: Potentials, barriers and options for support.'

Energy Policy 38(9): 4945-4954. 
Power, M., P. NeWelL, L. BAKer, H. Bulkeley, J. KiRShner AND A. SMith (2016). 'The political economy of energy transitions in Mozambique and South Africa: The role of the Rising Powers.' Energy Research \& Social Science 17: 10-19.

Practical ACTION, P. (2016). Poor people's energy outlook 2016: National Energy Access Planning from the Bottom Up. Rugby, Practical Action Publishing.

ROSSET, P. (2009). 'Agrofuels, Food Sovereignty, and the Contemporary Food Crisis.' Bulletin of Science, Technology \& Society 29(3): 189-193.

SCHUT, M., M. SLINGERLAND AND A. LOCKE (2010). 'Biofuel developments in Mozambique. Update and analysis of policy, potential and reality.' Energy Policy 38(9): 5151-5165.

Sebitosi, A. B. AND A. DA GraçA (2009). 'Cahora Bassa and Tete Province (Mozambique): A great potential for an industrial hub in Southern Africa.' Energy Policy 37(5): 2027-2032.

SIMON, D. (2016). Rethinking Sustainable Cities: Green, Fair, Sustainable. Bristol, Policy Press.

Sitoe, A., I. Remane, R. Ribeiro, M. P. Falcão, R. Mate, J. NhamirRe, S. Walker, L. MurRay and J. Melo (2016). 'Identificação e análise dos agentes e causas directas e indirectas de desmatamento e degradação florestal em Moçambique Maputo, Centro de Estudos de Agricultura e Gestão de Recursos Naturais and Winrock International.

SOKONA, Y., Y. MULUGETTA AND H. GUJBA (2012). 'Widening energy access in Africa: Towards energy transition.' Energy Policy 47, Supplement 1(0): 3-10.

SOVACOOL, B. K. (2014). 'What are we doing here? Analyzing fifteen years of energy scholarship and proposing a social science research agenda.' Energy Research \& Social Science 1: 1-29.

TRAUGER, A. (2014). 'Toward a political geography of food sovereignty: transforming territory, exchange and power in the liberal sovereign state.' The Journal of Peasant Studies 41(6): 1131-1152.

VAN DER PLOEG, J. D. (2014). 'Peasant-driven agricultural growth and food sovereignty.' The Journal of Peasant Studies 41(6): 999-1030.

VASCO, H. AND M. COSTA (2009). 'Quantification and use of forest biomass residues in Maputo province, Mozambique.' Biomass and Bioenergy 33(9): 1221-1228.

ZULU, L. C. AND R. B. RICHARDSON (2013). 'Charcoal, livelihoods, and poverty reduction: Evidence from subSaharan Africa.' Energy for Sustainable Development 17(2): 127-137. 